\title{
Teacher training: technology helping to develop an innovative and reflective professional profile
}

\author{
Pedro Hepp K. ${ }^{1}$, Miquel Àngel Prats Fernández ${ }^{2}$ and Josep Holgado García ${ }^{3}$ \\ 1. Pontificia Católica University (UC), Chile | phepp@uc.cl \\ 2. Ramon Llull University (URL), Spain | miquelpf@blanquerna.url.edu \\ 3. Rovira i Virgili University (URV), Spain | josep.holgado@urv.cat \\ Submitted in: November 2014 \\ Accepted in: March 2015 \\ Published in: April 2015
}

\section{Recommended citation}

Hepp K., P., Prats Fernández, M. À, \& Holgado García, J. (2015). Teacher training: technology helping to develop an innovative and reflective professional profile. RUSC. Universities and Knowledge Society Journal, 12(2). pp. 30-43. doi http://dx.doi.org/10.7238/rusc.v12i2.2458

\begin{abstract}
The society of the early twenty-first century is characterized as the knowledge society. Schools cannot afford to remain detached from the fast-moving changes that are taking place and have therefore made innovation one of their main priorities. One of the most profound changes and innovations experienced in the last few years concerns digital technologies. While knowledge and mastery of digital tools and processes are guarantees of equity in the education system, schools also have to face the challenge of making digital tools and applications available to all their pupils without neglecting any aspect of their educational function. At the same time, teachers must also involve themselves in the digital competences that are the unavoidable landmarks of the education of today and of the future. As with other professions in other sectors, being familiar with these digital tools and processes, mastering them and constantly updating them are now components of the teaching profession.

When viewing these new learning environments from a general transformational perspective and the technology-related teacher-training perspective, we need to bear in mind the following three dimensions:

Firstly, both initial and continuous teaching training programs should largely focus on developing the competences teachers need to use information and communication technologies (ICTs) for teaching purposes. Continuous training should be organized around the teacher's autonomous learning but it should also incorporate a training and implementation strategy that is based on work carried out by teams of teachers.

Secondly, the undeniable emergence of new codes and languages that have their origin in digital technologies brings new ways of thinking and doing and new ways of learning and accessing knowledge. It also means that teachers must be prepared to abide by a set of professional ethics and standards that require them to work individually and collectively to conceptualize the educational role that should be played by digital technologies.

Thirdly, the signs of the times require us to think about creating teaching center models that incorporate pedagogical innovations and open, flexible, creative, real and participatory digital projects and in which digital technologies can be the best pretext for innovation and for encouraging creativity in the classroom in order to introduce cross-disciplinary and organizational changes and open up schools to the community. These digital projects should make teachers question their individual roles, promote teamwork and involvement with others, generate synergies with other departments and areas as well as other teaching centers and their staff, and, finally, help to realize the dream of being "networked and web-based".
\end{abstract}

\section{Keywords}

$I C T$, initial training, teaching staff, innovation, pedagogy, reflection 


\section{Formación de educadores: la tecnología al servicio del desarrollo de un perfil profesional innovador y reflexivo}

\section{Resumen}

En la sociedad de principios del siglo XXI, caracterizada como la sociedad del conocimiento, la institución escolar no puede permanecer ajen a a los ritmos del cambio actual, por lo que la innovación constituye una de sus principales y prioritarias tareas. Es obvio que las innovaciones y los cambios más profundos que hemos experimentado en estos últimos años han venido de la mano de las tecnologías digitales. En este sentido, el conocimiento y el dominio de las herramientas y los procesos digitales supone una garantía de equidad en el sistema educativo, así como un reto para la escuela, que debe poner al alcance de todos sus alumnos las herramientas y las aplicaciones de la tecnología digital sin renunciar a su función educativa. Asimismo, el profesorado no puede quedar al margen de unas competencias digitales que son hitos ineludibles de la educación actual y futura. El conocimiento, el dominio y la constante actualización de estos procesos y herramientas digitales ahora son parte de la profesión docente, al igual que les ha sucedido a otros muchos profesionales de otros sectores.

Teniendo en cuenta los nuevos escenarios de aprendizaje, en general, desde una perspectiva transformadora y, en particular, desde la formación de los educadores en relación con la tecnología, pueden destacarse tres dimensiones.

En primer lugar, el esfuerzo de la formación del profesorado, tanto inicial como permanente, debe centrarse, en gran parte, en el desarrollo de las competencias necesarias para la utilización docente de las tecnologías de la información y la comunicación (TIC). En el caso de la formación permanente, esta debe articularse en torno al aprendizaje autónomo del profesor, pero con una estrategia de formación e implementación basada en el trabajo en equipos docentes.

En segundo lugar, la indiscutible emergencia de nuevos códigos y lenguajes originados en las tecnologías digitales implica nuevas formas de pensar y hacer, y nuevas maneras de aprender y de acceder al conocimiento. Esto le supone tal exigencia ética y deontológica al profesorado que este tiene que trabajar tanto individual como colectivamente en la conceptualización del papel educativo de las tecnologías digitales.

En tercer y último lugar, los signos de los tiempos nos exigen pensar en modelos de centros educativos que incorporen innovaciones pedagógicas y proyectos digitales abiertos, flexibles, creativos, reales y participativos; centros en los que las tecnologías digitales puedan ser el mejor pretexto para innovar y fomentar la creatividad dentro del aula, para provocar cambios transversales y organizativos, y para abrir la escuela a la comunidad. Estos proyectos digitales deberían interpelar personalmente y fomentar el trabajo en equipo y la complicidad con el compañero; generar sinergias con otros departamentos, áreas, claustros y centros; y en el fondo, permitir hacer realidad el sueño de encontrarse en red y en la red.

\section{Palabras clave}

TIC, formación inicial, profesorado, innovación, pedagogía, reflexión 


\section{Introduction}

Bearing in mind that technology can help to construct new environments, new perspectives and different educational and cultural modalities, the knowledge society should discern how technology affects the information society, the communication society, and the network society.

Some of the questions raised concern the need for new training environments that are in accordance with the teacher's profile; involve issues such as: who generates the contents?, how will these contents be transmitted and evaluated?; and propose the generation of networks for promoting collaborative and cooperative work.

In response to these questions, actions should be proposed that enable educators to become technologically competent and allow the users of this instruction and training process to acquire a set of skills, techniques, attitudes and habits that require the correct use of technological tools and provide for a successful teacher-training process.

We live in a society in which technological change is the order of the day. Pupils are sensitized to the world of technologies. Educators should therefore take advantage of this new source of intrinsic motivation by using these technologies and incorporating them to develop activities that encourage pupils to take an active part in their learning processes. This will increase the possibility of promoting specific types of learning activities, enable the development of thinking strategies, and construct significant types of learning that enable users to interact with each other while also stimulating their personal activity level.

Using technologies enables information to be acquired, processed, stored and disseminated and makes it possible to train individuals who can adapt to the new social challenges.

Teacher training should be geared towards reflections on processes that can lead to projects aimed at promoting the pedagogical use of tools, resources, programs, services and environments that enable technological tools to be made available at any moment.

The contents of teacher training programs should be related to teacher digital competence, the role of teacher training centers, new professional profiles, the professionalization of teachers, and the development of teachers' professional careers.

We need to reflect on processes that may be considered high quality when considering the pedagogical use of the tools, resources, programs, services and environments that readily available technologies can provide us. Proposal should be drawn up whereby teacher training programs and the digital competences these programs teach are directly related and are catalysts for change and educational success.

The main aim of this article is to study and analyze the education process, particularly with regard to the training of teachers. We also present the conclusions of the participatory diagnostic process conducted by a group of national and international experts in this area.

\section{Key ideas, recommendations and proposals for the training of teachers}

\subsection{Key ideas}

\subsubsection{On education policy and initial teacher training}

Today's knowledge-generation process contains a mixture of shared learning and collaboration that requires a balanced combination comprising a cognitive component, an emotional component, and a large supply of social skills. 
Bearing in mind that information is increasingly accessible thanks to the advent of ICTs, a teaching profile that is based on the mere transmission of teaching content is now meaningless. The teacher's role is no longer to provide pupils with information but to guide them through the process of searching and treating information so that they become responsible for actively and experimentally constructing their own knowledge.

If we take into account society's demand for the technological training of its teachers, the time devoted to ICTS in the curricula of university teacher-training programs is insufficient. Technological training must focus on the pedagogical application of digital tools rather than on their use.

Below are just some of the essential competences teachers need in order to exercise their profession in the twenty-first century:

\author{
1. Subject competence \\ 2. Teaching competence \\ 3. The ability to combine theory and practice \\ 4. Cooperation and collaboration \\ 5. Quality assurance \\ 6. Mobility \\ 7. Leadership \\ 8. Continuous learning
}

\title{
2.1.2 On change management
}

We need to understand and accept that the "map" of teaching and learning processes is not exactly the real "territory" of the classroom or of each pupil. First and foremost, teachers should have an open (which is not to say naïve) attitude. They should be prepared to "explore" the possibilities provided by technological tools for renewing their teaching and learning environments, i.e. they should allow themselves to be surprised and should not have any pre-judgements when meeting the challenges posed by technology.

Secondly, rather than working alone, teachers should work in teams, sharing their classwork with other teachers. Online technology-supported collaborative work can help enormously in this area.

Thirdly, teachers should document what they do and share their innovations. We have excellent professionals who innovate every day but who do not write down what they do.

Fourthly, we need to bear in mind and understand the contexts and the "mental maps" of our teachers regarding innovation and change. Change management has more to do with fear and emotion than with rational concerns.

And finally, we need a vision of innovation that gives us the opportunity to experiment and make mistakes without becoming "paralyzed" or immobile. Learning from mistakes enables us to learn and to progress.

\subsubsection{On teachers'skills development}

Numerous studies have stressed the importance of developing skills to ensure that individuals take part in the knowledge society of the twenty-first century (Ananiadou \& Claro, 2009; Claro et al., 2012; Pedró, 2006; Sánchez, Salinas, \& Harris, 2011). These skills, usually termed "of the twenty-first century" (Claro et al., 2012; Partnership for $21^{\text {st }}$ Century Skills, 2014), go beyond functional skills like knowing how to use a computer or different software. Although there are different approaches regarding the nature of these skills, it is usually agreed that they involve higherlevel knowledge that is linked to creative activities as well as to innovation, communication and collaboration, 
information management, problem solving, citizenship and the ethical challenges that have become critical in digital environments (Ananiadou \& Claro, 2009; Bennett, Maton, \& Kervin, 2008; Claro et al., 2012; ISTE, 2014; Sánchez, Salinas, Contreras, \& Meyer, 2011).

For pupils to develop these skills, teachers must be able to master them and be capable of teaching them. Studies on the knowledge and practices teachers need in order to teach these skills are consistent with the importance given to teachers to make improvements in the education systems (Barber \& Mourshed, 2007; Darling-Hammond \& Bransford, 2005; Twining, Raffaghelli, Albion, \& Knezek, 2013).

Numerous countries and organizations have developed standards aimed at improving teacher performance. Some, including the ISTE Standards (formerly the NETS) for Teachers' and the UNESCO ICT Standards for Teachers (UNESCO 2011) incorporate the knowledge and practices needed to help develop students' twenty-first century skills.

UNESCO ICT Standards for Teachers

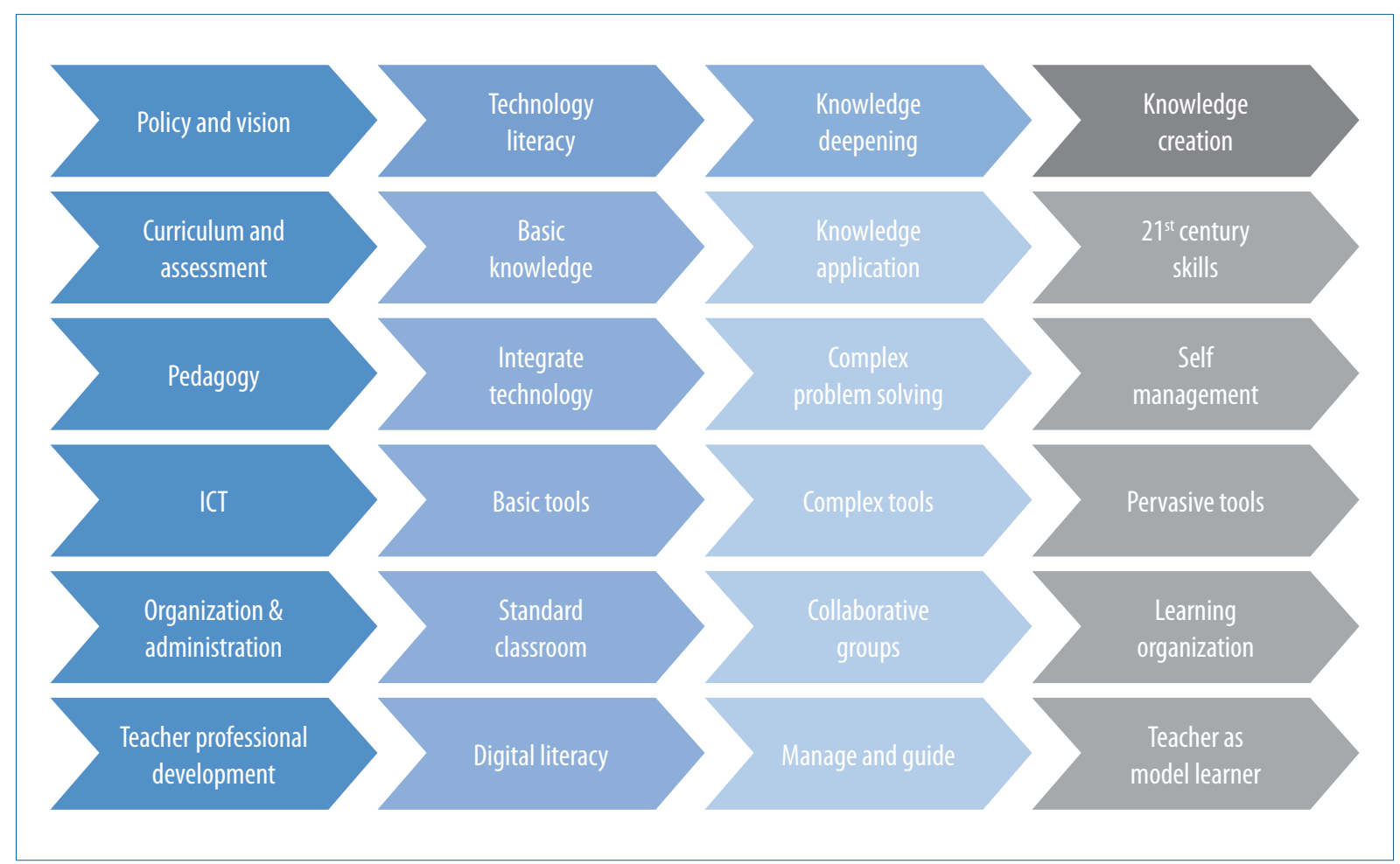

\subsubsection{On Teacher Initial Training}

Studies on incorporating digital technologies into teachers' initial training are still quite rare (Silva, 2014). According to Brun and Hinostroza (2011), ICTs are integrated into the curriculum only in specific areas and are not crossdisciplinary. Moreover, ICT-related teacher competences are present as specific objectives in less than half of thsyllabuses. According to the above authors, the main problem for teachers in training appears to involve how they should integrate ICTs into their future careers as teachers rather than learning how to use the ICTs themselves.

1. ISTE Standards: www.iste.org/standards/standards-for-teachers 
From a theoretical point of view, and by way of a framework for reflecting on the integration of ICTs into learning environments, Mishra and Koehler (2009) provided a conceptualization of ICTs that was based on a distinction proposed by Shulman (1986): pedagogical content knowledge, which refers to the instructor's content knowledge that is teachable. The conceptualization proposed by Mishra and Koehler incorporates another type of knowledge: knowledge of technology.

This concept of Technological Pedagogical Content Knowledge (TPACK) is illustrated by Mishra and Koehler using three circles, one of which contains pedagogical knowledge, one of which contains content knowledge, and the other contains technological knowledge, with intersections between all three. The area of intersection between all three circles, i.e. all three types of knowledge, is called TPACK. TPACK is a proposal for constructing a new type of knowledge that is not normally available in training institutions and comprises content, pedagogy and technology. It is a response to the question: What technology linked to what pedagogy can help students to learn what content?

TPACK has attracted growing interest among researchers and has begun to guide efforts to integrate ICTS at various levels of education ( $\mathrm{Wu}, 2013)$. Numerous experiments have been conducted in higher education and these have been used to design courses and instruments for measuring TPACK (Chai, Ling Koh, Tsai, \& Lee Wee Tan 2011; Schmidt et. al., 2009).

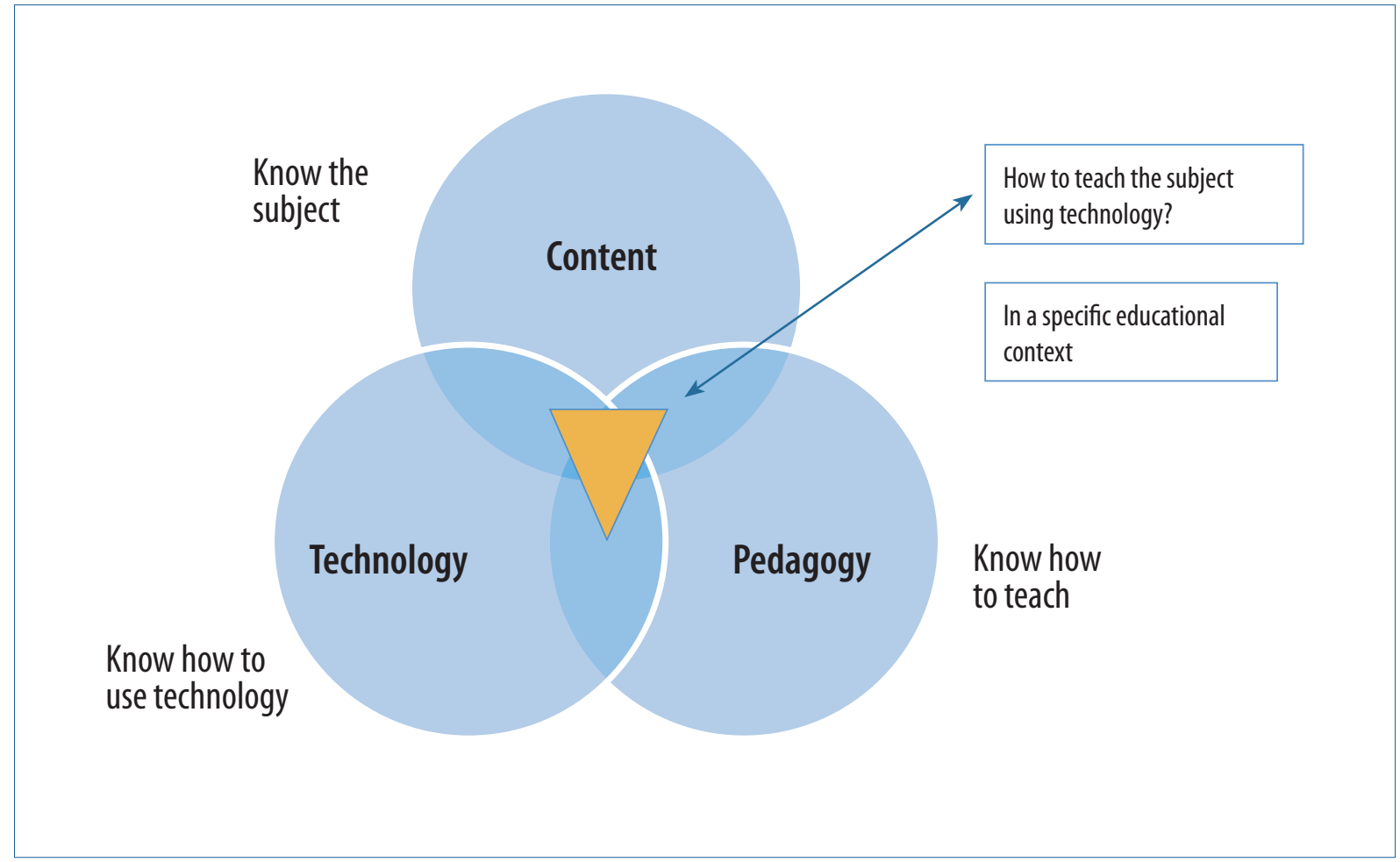

\subsubsection{On new proposals for ICTs in education}

In an increasing number of countries, attention paid to topics such as "computational thinking" and "programming" as part of the school curriculum is growing. This is reflected in the introduction of new curriculum areas for "Computation", "Computing" and "The Science of Computation", even in the first years of primary education (Berry, 
2013). The new curriculum in England, for example, states that: "A high-quality computing education equips pupils to use computational thinking and creativity to understand and change the world."2

\subsubsection{On challenges or barriers to the integration of ICTs in education}

The integration of ICTs into education systems brings with it a series of challenges and barriers that institutions need to tackle as a whole (Zhao, 2002, Yung-Jo, 2012). These challenges and barriers are summarized in the following table.

\section{Challenge or barrier}

\begin{tabular}{|l|l|}
\hline 1st Order & \\
\hline The institution & Institutional practices, available ICT structures, flexibility to make changes to the curriculum. \\
\hline The student & Digital culture and personal ICT infrastructure. \\
\hline 2nd Order & Self-efficacy, attitudes towards ICTs, personal ICT infrastructure, perceived incentives. \\
\hline The teacher & $\begin{array}{l}\text { Knowledge of the contribution of ICTs to enrichment of learning environments and resolution of learning or teaching } \\
\text { nodes in the teacher's specific topic areas or subjects; the type of ICT to use (hardware and software) and how to use } \\
\text { them both inside and outside the classroom. }\end{array}$ \\
\hline 3rd Order & The discipline
\end{tabular}

First-order barrier: the institution and the student. Like all institutions, schools and universities have rules and traditions, a certain level of technological infrastructure, and support services to enable it to be used. The challenge of integrating ICTs into their students' education means that institutions must introduce changes in their curricular structures, update their technological infrastructure, and take other decisions that will directly affect their teachers and students. These challenges, which are called "First-order barriers", comprise the following dimensions:

The "digital culture" of the institution, which is associated with its practices, regulations, and the leadership displayed by its authorities. The recommended way to overcome this barrier is to create an ICT integration project that incorporates objectives, ICT resources, indicators of integration, monitoring of progress, instruments for assessing students' ICT skills, and recognition of teachers' time commitment and is supported within a significant theoretical framework such as TPACK (Mishra and Koehler, 2009).

The technological infrastructure of the institution and the technical-pedagogical support available for its academic staff. The technological infrastructure is an essential barrier to tackle when integrating ICTs into an educational establishment. One of the first barriers identified (NCES, 2000), it is associated with quality, quantity and availability of ICT resources at an institution, particular for use in the classroom. Other barriers are the speed and efficiency with which problems are prevented or corrected by the institution's technical support staff.

Students' "digital culture" has changed fundamentally in the last decade. The so-called "Digital Natives" or "Learners of the New Millennium" (Pedró, 2006 and 2011; Prensky, 2009) have acquired a basic layer of technological skills. However, recent studies have shown that although students can operate mobile devices, social networks

2. Computing programmes of study: key stages 1 and 2; National curriculum in England. http://www.computingatschool.org.uk/data/uploads/ primary_national_curriculum___computing.pdf 
and videogames efficiently, this does not necessarily mean that they are automatically able to use software for educational purposes.

Pedró (2006) suggests that when these technologies began to enter people's homes, the ICT-related competences of pupils started to outperform those of their teachers. This author also suggests that we can expect a demand for greater variety and quality in the use of ICTs in schools and universities, particularly with regard to the kind of ICT devices and services available at schools, the frequency of their use, the range of possible teaching activities, the opportunities for collaborative work and networking, and the standards of digital quality in terms of interactivity and use of multimedia resources.

Second-order barrier: the teacher. This barrier is associated with the teachers themselves. It refers to teachers' attitudes towards using technologies in their teaching activities, their sense of self-efficacy when using them in their classrooms, their perception of the effort needed to prepare and teach a class using technology, and their opinion of how efficient this effort is for achieving more or better learning and increasing motivation.

Third-order barrier: the discipline. Even when the institution has overcome the first two barriers, it is still not certain that teachers will introduce ICTs into their teaching strategies because each discipline presents its own specific challenges because of the role, advantages and obstacles inherent in learning resources. The difficulty lies in how to justify the use of technologies in a particular subject and how to respond clearly to the following questions: What do these technologies contribute? Do they help to improve learning? Do they enrich the teaching and learning environments? Do they need special support? Which software should be used? How can we evaluate learning when using technologies? Will the pupils be able to transfer these practices and technologies to their future work environments?

Overcoming this disciplinary barrier is a long-term endeavor that requires institutional support. Key elements in this endeavor are peer networks to identify practices by other teachers of similar subjects who have successfully tested the use of technologies and can provide models for their use in those subjects (OECD, 2011).

\subsection{General recommendations}

\subsubsection{On initial teacher training institutions}

In our current socio-technological context, one of the missions of initial and continuous teacher training is to prepare for the inevitable superseding of teaching practices that are based on the direct transmission of knowledge and a rigid organization of teachings, especially at the secondary level where curriculums are overloaded with objectives and obligatory contents and evaluation criteria are static. A specific objective of this training should be to provide knowledge of the various types of educational applications (practice, simulations, tutorials, and games, etc.).

\subsubsection{On innovation with technological support}

The emphasis in current curriculums on the acquisition of competences requires further interaction between pupils and teachers. Attending to a diverse range of pupils and meeting a range of different needs leads to the individualization of learning experiences. Promoting skills for collaboration and teamwork means that teachers have to organize, observe and support teambuilding. Enabling students to reflect, explain and contribute actively means that teachers have to organize, observe and monitor student discussions, demonstrations and 
presentations. Bringing teaching activities closer to real external situations means that teachers have to propose activities that incorporate examples and real-world applications.

Incorporating digital technologies as a resource for teachers and an instrument that enables students' intellectual work is another of these important changes. This means that teaching can definitely not be considered a static role that is "learned" once and for all. The predisposition to lifelong learning that is today required of any educated person begins with the exercise of the teaching function.

\subsubsection{On teacher digital competence}

Expressions such as "digital natives" and "the Facebook generation" express a generational fact that is associated with the familiarity young people have with technology. Many schoolchildren have a large background of knowledge, experiences and digital skills, which are extensive but rather unstructured and cannot be equated with digital competence because they do not guarantee that children and adolescents will learn and gain added value in their academic work by using technology. As teachers observe every day, being born in a socio-technologically rich context does not automatically imply that one is capable of working and studying in digital environments profitably and efficiently. Frequently using messaging systems and participating in social networks is not synonymous with mastering communication, while searching for information and using office automation tools (often little more than simply copying and pasting) is not the same as producing or managing knowledge.

For this reason, a leading and integral objective of promoting digital competence in schoolchildren should be to enable them to moderately, judiciously and productively use Internet resources and their available devices to manage their online identity and protect themselves from security risks.

Digital competence can be understood as the set of knowledge, strategies and skills that enable an individual to solve typical and emerging problems (i.e. those related to the future and to the new situations being produced) associated with the digital world in relation to communicating, selecting information and writing, etc., using a digital support.

Digital competence has an additional dimension that relates to the nature of the technological systems and instruments as the object of knowledge. The intellectual activity associated with programming teaches one to think in an abstract, logical and structured way, fosters the development of an autonomous and innovative mentality, and helps to develop "computational thinking", i.e. the reasoning and intuition that helps learners to develop problem-solving strategies. In some countries, "computational thinking" is gaining importance in compulsory education.

\section{Actions and proposals}

ICTs provide an opportunity for changing and transforming education, improving teacher digital competence, updating methodologies, and improving student learning. They should therefore be viewed as an opportunity rather than a threat.

We need to draw up a map of educational innovation and create a research agency or institute for pedagogical innovation that provides ITC support to schools (Living Edulab). 
The technological and pedagogical maturity of schools should be evaluated and both teachers and pupils should be provided with accreditation for their ITC competences.

Dialogue should be promoted between the business technology world and the educational environment. The creation of an international event and meeting point for technological innovation applied to education would also be interesting.

The idea is not so much to install technology in the classrooms but to create a new model for schools that incorporates the presence of technology. School management should be empowered with digital competences and teachers should be given the opportunity to develop more efficient teaching and learning processes with the aid of technology while ensuring that the processes work better than when technology is not used.

School autonomy, integrated functioning, decentralized management, flexibility to adapt to the changing needs of society, and the involvement of the school community are the organizational principles that should govern the education system. School governance and educational leadership should respond to these principles, to whose development digital technologies are inherent. The actions of schoolteachers in both public and private teaching institutions should be coherent with these principles.

A technological and pedagogical handbook (for What?, Who?, and How?) should collect and systematize the various education-related technological solutions, identify technology sector suppliers and companies that can offer these services, and outline emerging methodologies and pedagogies related to the use of technology.

A systematic and comprehensive analysis of the most suitable teaching methods for working with technology in the classroom should be drawn up.

An ICT Integration Plan should be drawn up from a pedagogical rather than a technological perspective. While infrastructure should be considered in the development of this plan, the focus should be on the quality and relevance of the use of technology for pedagogical purposes. The plan should include progress indicators to monitor the effectiveness and impact of the strategies adopted.

Diagnoses of the ICT culture prevailing at teaching centers should be made periodically. The quality of the center's infrastructure and services perceived by users should also be assessed, with special regard to their pedagogical uses both inside and outside the classroom. Other aims of these diagnoses would be to identify the challenges or barriers prevailing at the institution, determine what strategies should be used to overcome them, and apply these strategies

Incorporation of ICTs in the classroom. The institutions that are the most advanced in their incorporation of ICTS have been able to recognize and overcome numerous barriers to their incorporation, including those related to infrastructure self-efficacy, etc., and to overcome what is considered the most complex barrier, i.e. how to apply ICTs in a specific curricular area, in a particular classroom context, and with a suitable pedagogical method.

Peer networks. Links should be established and promoted between the teachers of different institutions who work in similar contexts. The literature shows that an effective way to progress is to work via horizontal channels with peers who share similar challenges and situations. 


\section{References}

Ananiadou, K., \& Claro, M. (2009). 21 $1^{\text {st }}$ century skills and competences for new millenium lerners in OECD countries. In OECD (Ed.), Working Papers (vol. 41). France. doi: http://dx.doi.org/10.1787/218525261154

Barber, M., \& Mourshed, M. (2007). How the World's Best School Systems Come Out on Top. In M. Company (Ed.). London: McKinsey Company.

Bennett, S., Maton, K., \& Kervin, L. (2008). The digital natives debate: A critical review of the evidence. British Journal of Educational Technology, 39(4), 773-964. doi: http://dx.doi.org/10.1111/j.1467-8535.2007.00793.x

Berry, M. (2013) Computing in the national curriculum. A guide for primary teachers. Bedford: Computing at School.

Brun, M., \& Hinostroza, J. E. (2011). Research on ICT integration for enhancing quality in teacher education: Nationwide policy or global challenge? In E. Eisenschmidt, \& E. Löfström (Eds.), Developing quality cultures in teacher education: Expanding horizons in relation to quality assurance (pp. 99-118). Tallinn: OÜ Vali Press.

Chai, C. S., Ling Koh, J. H., Tsai, C.-C., \& Lee Wee Tan, L. (2011). Modeling primary school pre-service teachers'Technological Pedagogical Content Knowledge (TPACK) for meaningful learning with information and communication technology (ICT). Computers \& Education, 57(1), 1184-1193. doi: http://dx.doi.org/10.1016/j.compedu.2011.01.007

Claro, M., Preiss, D. D., San Martín, E., Jara, I., Hinostroza, J. E., Valenzuela, S., \& Nussbaum, M. (2012). Assessment of $21^{\text {st }}$ century ICT skills in Chile: Test design and results from high school level students. Computers \& Education, 59(3), 1042-1053. doi: http://dx.doi.org/10.1016/j.compedu.2012.04.004

Darling-Hammond, L., \& Bransford, J. (Eds.). (2005). Preparing Teachers for a Changing World: What Teachers Should Learn and Be Able to Do. San Francisco, CA: Jossey-Bass.

ISTE. (2014). ISTE Standards for Students. Retrieved from https://http://www.iste.org/standards/standards-forstudents

Mishra, P., \& Koehler, M. (2009). What Is Technological Pedagogical Content Knowledge? Contemporary Issues in Technology and Teacher Education, 9(1), 60-70.

Morin, E. (2001). Los siete saberes del futuro. Madrid: Santillana.

Rizza, C. (2011). ICT and Initial Teacher Education. National Policies. OECD Directorate for Education, Working Paper No. 61

Partnership for $21^{\text {st }}$ Century Skills. (2014). Framework for 21st Century Learning. Retrieved from http://www.p21.org/ our-work/p21-framework

Pedró, F. (2006). The New Millenium Learners: Challenging our Views on ICT and Learning. OECD-CERI, pp. 1-17. Retrieved from www.oecd.org/dataoecd/1/1/38358359.pdf

Pedró, F. (2011). Tecnología en la escuela: Lo que funciona y porqué. Madrid: Fundación Santillana.

Perrenoud, P. (2004). Diez nuevas competencias para enseñar. Barcelona: Graó.

Prensky, M. (2009). Digital Wisdom (H. Sapiens Digital). Moving beyond Natives and Immigrants. Innovate, 5(3). Retrieved from http://www.marcprensky. com/writing/default.asp

Sánchez, J., Salinas, A., \& Harris, J. (2011). Education with ICT in South Korea and Chile. International Journal of Educational Development, 31(2), 126-148. doi: http://dx.doi.org/10.1016/j.ijedudev.2010.03.003

Sánchez, J., Salinas, A., Contreras, D., \& Meyer, E. (2011). Does the New Digital Generation of Learners Exist? A Qualitative Study. British Journal of Educational Technology, 42(4), 543-556. doi: http://dx.doi.org/10.1111/j.14678535.2010.01069.x

RUSC Vol. 12 No 2 Special Issue | Universitat Oberta de Catalunya and University of New England | Barcelona, April 2015 @) P. Hepp K., M. A. Prats Fernández and J. Holgado García | @ by FUOC, 2015 | Teacher training: technology helping to develop.. 
Schmidt, D. A., Baran, E., Thompson, A. D., Mishra, P., Koehler, M. J., \& Shin, T. S. (2009). Technological Pedagogical Content Knowledge (TPACK): The Development and Validation of an Assessment Instrument for Preservice Teachers. Journal of Research on Technology in Education, 42(2), 123-149. doi: http://dx.doi.org/10.1080/15391523.2009.10782544 Silva, J., \& Salinas, J. (2014). Innovando con TIC en la formación inicial docente: aspectos teóricos y casos concretos. Santiago: Enlaces.

Twining, P., Raffaghelli, J., Albion, P., \& Knezek, D. (2013). Moving education into the digital age: the contribution of teachers' professional development. Journal of Computer Assisted Learning, 29(5), 426-437. doi: http://dx.doi. org/10.1111/jcal.12031

UIS. (2012). ICT In Education in Latin America and the Caribbean: A regional analysis of ICT integration and e-readiness. Montreal, Canada: UNESCO Institute for Statistics.

UNESCO. (2011). Normas sobre competencias TIC para docentes. Retrieved from http://www.oei.es/tic/normas-ticmodulos-competencias.pdf

Wu, Y. T. (2013). Research trends in technological pedagogical content knowledge (TPACK) research: A review of empirical studies published in selected journals from 2002 to 2011. British Journal of Educational Technology, 44(3), 73-76. doi: http://dx.doi.org/10.1111/j.1467-8535.2012.01349.x

Yun-Jo, A. (2012). Creating Technology-Enhanced, Learner-Centered Classrooms: K-12 Teachers'Beliefs, Perceptions, Barriers, and Support Needs. Journal of Digital Learning in Teacher Education, 28(2), 54-62.

Zhao, Y., Pugh, K., Sheldon, S., \& Byers, J. (2002). Conditions for Classroom Technology Integration. Teachers College Record, 104(3), 482-515. doi: http://dx.doi.org/10.1111/1467-9620.00170

\section{About the authors}

Pedro Hepp K.

phepp@uc.cl

ORCID ID: http://orcid.org/0000-0002-4801-4837

Civil engineer from the Pontificia Católica University (UC), Chile. PhD in Computer Science from the University of Edinburgh

Pedro Hepp K. is a professor at the School of Education of the Pontificia Católica University (Chile), president of the Araucaní Aprende Foundation (www.araucaniaprende.cl), and director of the Educaraucanía Foundation (http://www. educaraucania.com/) and the País Digital Foundation (http://www.paisdigital.org/). He founded the "Enlaces" program of the Chilean Ministry of Education and was national coordinator for the program from its inception until 2001. He has also been the director of the Instituto de Informática Educativa of the La Frontera University in Chile. His main areas of interest and research concern the use of digital technologies in initial teacher training programs and the use of digital technologies for creating content and constructing programmable artifacts for basic education in low-income urban and rural sectors.

Facultad de Educación de la Pontificia Universidad Católica de Chile

Vicuña Mackenna 4860

Santiago

Chile 


\author{
Miquel Àngel Prats Fernández \\ miquelpf@blanquerna.url.edu \\ ORCID ID: http://orcid.org/oooo-0002-9542-7888?lang=en \\ Tenured professor at the Ramon Llull University (URL); Director of the Degree in Early Childhood Education \\ at the Blanquerna Faculty of Psychology, Education and Sport Sciences (FCPEE) at the URL
}

A teacher and psychologist, Miquel Àngel Prats Fernández holds a PhD in Pedagogy from the Faculty of Psychology, Education and Sport Sciences of the Ramon Llull University in Barcelona. He is a professor of Educational Technology and leading researcher of the eduTIC line of the PSiTIC (Pedagogy, Society, Innovation and ICT) research group of the Blanquerna FCPEE of the URL. He is also the coordinator of the Official Master's in Educational Innovation and Educational Leadership and a collaborator on the Edu21 Project. In recent years he has been the director of the Ituarte Technology Center (CETEI) of the Joan XXIII Foundation and director of the first five editions of ITworldEdu. Throughout his professional life, he has combined his university academic activities with communications activities through various media.

Universitat Ramon Llull

Císter, 24-34

08022 Barcelona

Spain

\author{
Josep Holgado García \\ josep.holgado@urv.cat \\ ORCID ID: http://orcid.org/0000-0003-2636-0496
}

Professor in the Department of Pedagogy at the Rovira i Virgili University (URV) and coordinator of the Degrees in Child Education and Primary Education at the Terres de l'Ebre Campus of the Rovira i Virgili University (URV)

An educationalist and professor of secondary education, Josep Holgado García holds a PhD in Pedagogy from the School of Educational Sciences and Psychology (FCEP) of the Rovira i Virgili University (URV) in Tarragona and a Master's in Educational Technology: design of teaching materials and learning environments. He is currently the academic coordinator of the Degrees in Child Education and Primary Education at the Terres de l'Ebre Campus (CTE) of the URV, a professor in the Department of Pedagogy at the Faculty of Education Sciences and Psychology of the URV, and coordinator of the Education and Technology Laboratory (ETLAB) at the CTE. He is a member of the Applied Research Group in Education and Technology (ARGET) of the URV. He has worked at various infant, primary and secondary schools and as a trainer of nonuniversity teachers at the Institute of Educational Sciences of the URV. He has been a member of numerous management teams at infant, primary and secondary education teaching centers. He has been the coordinator of academic mobility at the FCEP of the URV and the coordinator of numerous innovation education experiences based on the curricular integration of computer applications. He has led several language programs in Catalonia and coordinated the UNESCO Associated Schools Plan at numerous teaching centers, where he helped to apply the education program for international cooperation and peace.

Universitat Rovira i Virgili

Carretera de Valls, s/n

43007 Tarragona

Spain

Original title: Formación de educadores: la tecnología al servicio del desarrollo de un perfil profesional innovador y reflexivo 


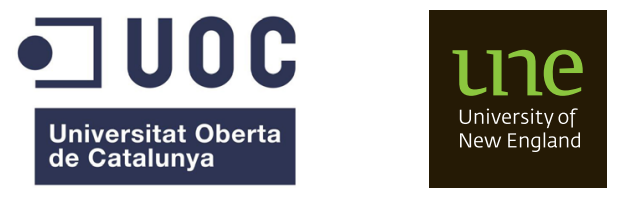

